\title{
Urban development projects catalyst for sustainable transformations: the need for entrepreneurial political leadership
}

\begin{abstract}
This article argues that lessons for sustainable urban transformations can be learned from a more precise understanding of urban political leadership in decision-making processes of far-reaching urban development projects. While urban governance networks and distributed forms of governing may be typical of contemporary urban political configurations, our results show the necessity of entrepreneurial political leadership in developing an agenda for sustainable urban transformations, in connecting policy streams and engaging stakeholders, and in aligning and deliberating between different interests. To map the role, impact and strategic behaviour of the dominant actors, especially the mayor, we reconstructed thoroughly the decision-making processes of three urban projects in the city of Kortrijk (Belgium). For this multiple case study we used a complexity acknowledging perspective and opted for qualitative research techniques.
\end{abstract}

\section{Keywords}

Urban projects; policy entrepreneurs; urban governance; mayor; urban sustainability

\section{Introduction}

Since the late 1980s urban development projects (UDPs) have become increasingly popular (Salet et al, 2006), also in Belgium and Flanders (Belgium's northern region). By UDPs we mean physicalspatial interventions that have pronounced consequences for urban development and that can act as catalysts for urban transformations. Brownfield sites become large shopping centres or green central parks, old industrial ports revitalise into creative city quarters and/or into sustainable construction sites, railway station areas transform in commercial office zones and/or stimulate sustainable urban mobility, etc. In this paper we will focus on the complex decision-making processes of UDPs. We will examine the strategic behaviour of the dominant actors within UDPs in a Belgian city. In particular, we want to describe how entrepreneurial political leaders are involved in these complex processes, how they use their power resources and what the impact is within the urban governance networks concerning these far-reaching projects.

During our in-depth empirical research in the city of Kortrijk (Belgium), it became apparent that the mayor was permanently laying connections between several policy processes, projects, actors, opportunities, etc. to realise UDPs in his city. These results on entrepreneurial mayoralism can be valuable for the discussion on and striving after sustainable urban transformations, because they add interesting insights to previous research on urban governance. In previous literature, it is already argued that urban decision-making is ever more the outcome of a process that proceeds via mixed networks of public and private actors, and less and less often a process within the context of formal, institutional, and bureaucratic government frameworks at just one single policy level (e.g. Pierre, 
1998; John, 2001; Berg et al., 2005; Klijn, 2008). In particular, one can recognize complex settings in the decision-making of UDPs where local politicians, top-level civil servants, autonomous public agencies, supra-local governments, investment companies, etc. are more or less intertwined within hybrid and autonomous coalitions. This growing complexity, fragmentation of decision-making and networked nature of governance puts particular strains on urban political leadership. This resulted in formal institutional transformations with strengthened roles for mayors and the shifting agenda of mayoral governance in Europe (Berg et al, 2005; Greasley et al., 2008; Steyvers et al., 2008; Parker, 2011). Although detailed case study research is almost lacking, it is argued that more and more mayors (or their functional equivalents as local political leaders) act as creative entrepreneurs and focus on interconnectivity, agenda-setting and network broking (Borraz et al., 2004). We believe that the mapping of the formal and informal political mechanisms within their 'real-life' context can improve our understanding of whether and how entrepreneurial political leadership can actively engage with and shape sustainable urban transformations.

These kind of political mechanisms are underdeveloped in current research and literature. And, more particularly, policy entrepreneurs have very rarely been the focus of discussion on sustainable (urban) transformations. In recent years, the sustainability challenges that our societies are facing, have increasingly been framed as a challenge of 'transitions' and there is a burgeoning academic literature on sustainability transitions. This literature often focuses on socio-technical systems (such as the energy, mobility or food system) and tries to understand how transitions in these systems develop and/or how they can possibly be influenced (Geels et al., 2007; Loorbach, 2007; Voß et al., 2009; Grin et al., 2010). In relation to sustainable urban transformations, the growing field of transition studies seems to have at least three weak points where it could benefit from additional research and insights. First, researchers active in the field often automatically take the national level as focus of analysis. This may underestimate the role of the local scale and the influence of different, interdependent scales on the urban level (STRN, 2010; Bulkeley et al., 2011; Coenen et al., 2012). Second, parts of the transition literature have repeatedly been criticised for underrating the role of power and politics, although during the last years several authors have started focusing on these questions (Scrase et al., 2009; Grin, 2010; Avelino, 2011; Meadowcroft, 2011). Third, guidelines for the governance of transitions are usually derived from the characteristics of transitions in sociotechnical systems and seem to apply largely independent of the context of the policy process (Grin, 2010). While this line of reasoning may be informative for the overall strategic orientation of transition governance, it gives no insights in the everyday strategies actors use in transition governance processes and the circumstances under which they have to take practical day-to-day decisions. A more sophisticated contribution from political and policy sciences (Meadowcroft, 2011) on themes such as decision-making processes, the role of leadership, policy entrepreneurs and governance networks is necessary. Although our empirical research did not start from a sustainability urban transition focus but from transformative UDPs fitting more in a neoliberal perspective (Swyngedouw et al., 2002), we nevertheless believe that our case study research can generate empirical insights about the local and distinctive institutional conditions (especially on urban political leadership) that can stimulate these transitions.

In this article we first describe interesting theoretical and analytical frameworks on policy and institutional entrepreneurship. Than we explain how we have studied the role, impact and strategic behaviour of the entrepreneurial mayor within the three decision decision-making processes of transformative UDPs in the city of Kortrijk. After a more or less chronological narrative of each case, we complete this article by offering some general conclusions and reflections about lessons that can be learned from this case study research for sustainable urban transformations. 


\section{Policy entrepreneurs initiate transformation}

\subsection{Coupling streams in complex settings}

Policy entrepreneurs can play an important role in articulating innovative ideas onto government agendas (Mintrom, 1997). Following Kingdon (1984), we define policy entrepreneurs as advocates of certain problems and/or solutions that are willing to invest resources (time, energy, reputation, money) to promote their ideas for policy change, either because of their concern for specific problems, their policy values, and/or for personal benefits. In their strive for change, they make use of several strategies to promote their ideas: identifying problems and promoting their solutions, shaping the terms of policy debates, developing close ties with people through whom they can realise their policy goals, and building coalitions with powerful actors (Kingdon, 1984; Baumgartner et al., 1993; Mintrom, 1997; Zahariadis, 2007). Policy entrepreneurs can come from different corners. Kingdon (1984: 180, 204) mentions elected officials, civil servants, lobbyists, academics, lawyers, and journalists.

According to Kingdon (1984) policy entrepreneurs try to influence the governmental and decision agenda and therefore they often focus on the coupling of three process streams that flow through the system: a stream of problems, of policies and of politics. The problem stream contains all conditions that become interpreted as problems. Agendas are influenced when some participants succeed in getting more attention for one problem than for another. In the policy stream ideas, proposals and alternatives float around in what Kingdon compares to 'a primeval soup' (Kingdon, 1984: 117). As such, policy-making is not only a matter of interest, power and strategy, but also of ideas and their influence. The political stream is determined by elections, changes in government, a new balance of power in parliament, swings in the mood of the public, interest group pressure campaigns. The coupling of the three streams is essential for moving items up the agenda. When a problem gets attention, a policy solution is available, and the political climate is receptive, than a moment for pushing change has arrived. This moment is called a 'policy window' by Kingdon (1984). Policy windows are scarce and are only open for a limited time period. Policy entrepreneurs try to create and respond to those moments. "They hook solutions to problems, proposals to political momentum, and political events to policy problems [...] Without the presence of an entrepreneur, the linking of streams may not take place" (Kingdon, 1984: 182).

Common to most perspectives on entrepreneurship is an appreciation that "the emergence of novelty is not an easy or predictable process as it is ripe with politics and ongoing negotiation [...] it has also had to come to grips with issues of agency, interests and power, but it has approached these from the perspective of change rather than continuity" (Garud et al., 2007: 961). Also Kingdon stresses that his model shows how policy change does not proceed neatly in causal stages or linear phases. There is some "messiness, accident, fortuitous coupling, and dumb luck" involved (Kingdon, 1984: 206). During our research, we assumed that any decision concerning UDPs must be seen as happening within a tangled series of decisions in which formal decisions and different decisionmakers can play a role, but this role depends to a large degree on the meaning given to the decisions in the many interactions among the actors involved. We did not expect one clear decision-making moment, but instead a rather intricate and intertwined series of decisions taken within a rather disorderly or chaotic process, and in which often an unplanned or accidental convergence of circumstances determines the decision-making (Cohen et al, 1972; Kingdon, 1984).

\subsection{Governance networks as institutional vehicle?}

Related to the process complexity and following the governance literature (cf. supra), we also assumed that UDPs are determined by a governance setting characterised by a fragmented, informal 
controlled and non-hierarchical government, by a competition between policy levels and urban actors, and by the impact of (semi) private actors (investment companies, NGOs, residents' associations, etc.). Nor the city government, nor the (semi) private actors have the authority, the knowledge and the capacities to handle UDPs alone (Salet et al, 2006). Therefore urban governance networks are formed. Central to most network approaches is interdependence or mutual dependence (Pierre, 1998; Marsh, 1998; Koppenjan et al.,2004: Klijn, 2008). According to Klijn (1996) a network is "a changing pattern of social relationships between interdependent actors, which takes shape around policy problems or policy programs and which is being formed, reproduced and changed by an ecology of games between these actors". Interdependence and the lack of a strict hierarchy do not mean that all involved actors wield the same power and that there is symmetry present. Which actors have the most impact depends on the power resources in their possession and the importance attached to these resources in the decision-making process.

If we consider formal and informal governance networks as institutional arrangements, than insights from research on institutional entrepreneurship are also relevant. This term refers to the "activities of actors who have an interest in particular institutional arrangements and who leverage resources to create new institutions or to transform existing ones" (Maguire et al., 2004: 657) and is closely associated with DiMaggio (1988: 14), who argued that "new institutions arise when organized actors with sufficient resources see in them an opportunity to realize interests that they value highly" (Garud et al., 2007). Research on entrepreneurship tends to emphasize how processes and institutions themselves are shaped by creative entrepreneurial forces that bring about change. Research on institutional entrepreneurship indicates that institutional structures do not necessarily constrain agency but, following Giddens (1984), may also serve as a vehicle for the unfolding of entrepreneurial activities. To qualify as institutional entrepreneurs, individuals must break with the dominant cultures, rules and practices and institutionalize alternative logics. That goes hand in hand with a intensely political process (Seo et al., 2002; Lowndes, 2005; Garud et al., 2007).

\subsection{Urban presidents as powerful entrepreneurs}

As Borraz and John note (2004: 112-113), the growing complexity and fragmentation of local decision-making calls not only for more but also for a particular kind of urban leadership. This tends to concentrate on its role in agenda-setting and network broking giving way to an entrepreneurial kind of mayoral leadership. Urban political leaders should "pull the shifting frameworks of local decision-making together, act as entrepreneurs in an increasingly competitive environment and function as figureheads of their locality" (John, 2001: 16-17). In countries with (quasi-)directly elected mayors and a dualistic conception of legislative-executive relations, mayors in cities could easily turn into a sort of urban presidents. In countries like Belgium, with a consensus oriented style of decisionmaking, it seems not obvious to develop a strong local leadership because of the constant search for all kind of balances. However, following Steyvers et al. (2008), also in Belgium urban political leadership becomes more presidential in the actual practices, although without thorough changes in formal institutional structures. Rather, roles are changing.

We argue that when 'urban presidents' invest their powerful resources in governance networks on the one hand (e.g. legitimacy, financial resources and power channels), and are able to couple streams during policy windows (or create policy windows) on the other hand, then there is a real chance that their strategic ideas, visions and interests will be translated into real policy change or even urban transformations. 


\section{Method: reconstructing complex processes}

Using a complexity-acknowledging perspective (Teisman, 2000; 2008), we reconstructed carefully and thoroughly the decision-making processes around three urban development processes and the power configurations within these processes (Dahl, 1961). We are fully aware that these reconstructions are always a (re)construction of the researcher in which the interest of the researcher, his perspective, plays a crucial role (cf. Latour, 1987). This and the fact that the researcher is not a decision maker in the governance settings of the UDPs, are the main reasons why the 'black box' of decision making cannot be opened entirely.

Given our focus, the qualitative case study approach is the most appropriate research method as it studies phenomena within their 'real-life context', thus enabling us to take full account of their complexity (Yin, 1984: 23). For our case studies we opted for several qualitative research methods and techniques (Miles et al, 1984). Firstly, our reconstructions of the decision-making processes are based on in-depth interviews with involved key figures. In total, we carried out 40 interviews with local and Flemish politicians, civil servants, private investors, representatives of semi-public corporations, project leaders from public agencies and academics. Some key figures have been interviewed more than once. During these interviews, we attempted to find out how the processes evolved and whom can leave one's mark, where and when (i.e. which actors are dominant and which power relations develop under which circumstances?). The interpretations of the various people interviewed were confronted with one another. Secondly, our research is also based on a detailed analysis of formal and informal (policy) documents.

The three urban development projects that we analyse below are all located in downtown Kortrijk. This city, with around 74.000 inhabitants, is one out of many core cities of the Flemish urban network. The three UDPs occupy a central position in formal strategic documents of the local government (e.g. political agreements, strategic multi-annual plan, spatial structural plans) and were mentioned as being of strategic importance to the city by local politicians and city officials during the interviews. All three selected UDPs were in the process of implementation at the time of our field work (i.c. in 2007-2008), and are scheduled for completion in the course of the current legislature (i.c. 2007-2012). The UDPs differ in the key decision-makers involved (apart from the local government), the source of financing and other dimensions of the UDP besides the physical-spatial intervention (leisure, culture, mobility, etc.).

Since 2011, the urban and architectural metamorphose of Kortrijk is visible for inhabitants and visitors. The amount of building excavations and traffic diversions is drastically diminished, the perception of livability has increased (City Monitor, December 2011) and innovative design lures specific tourists to the heart of the city. The three UDPs resulted not only in a real metamorphose of the physical space in the heart of the city, but also established a new strategic (dis)course for the commercial area, for culture and creation, and for innovation and the creative economy. The completion of our cases is certainly a feature of this and shows the transformative character of the three UDPs. In particular, we studied the decision-making process of the following UDPs:

(1) ' $\mathrm{K}$ in Kortrijk', the Foruminvest shopping complex. In the shopping area in the city centre of Kortrijk a large shopping centre with 85 shops, a designer high-rise block containing approximately 80 housing units and a large car park was built. The project was constructed and finished in 2010 on a neglected site that was once home a primary and secondary school. Foruminvest, a Dutch investment company, which has completed dozens of similar projects in a number of European countries, funded and developed the entire project. This investor and the Stadsontwikkelingsbedrijf Kortrijk (SOK), an autonomous municipal company, have opted here for a public-private partnership. 
Foruminvest invested EUR 160 million in its shopping centre, including a high-rise block of flats. This is at once the biggest private investment ever made in the city centre of Kortrijk. Moreover, the project is generating new initiatives such as the foundation of a Business Improvement District and a Building Fund.

(2) The Leie Improvement Project. In a nutshell this urban project involves straightening, deepening and broadening the river Leie in the centre of the city of Kortrijk to allow ships of up to 1,350 tonnes to pass (see fig. 1). This fits in with a European decision supported by the Belgian state and incumbing on the city of Kortrijk. These works have huge urban development repercussions for the city: the demolition of 5 bridges, the construction of 7 new bridges, the laying of boulevards, parks, a skatebowl, etc. The supralocal government considered these public works more as large-scale infrastructural works dictated by technical standards. In the beginning the city did not support the works. Influenced by various actors and processes the city of Kortrijk has gradually begun - especially in the 1990s and in leaps thereafter - to see the Leie Improvement Project more as a lever for high quality urban spaces. In the end the city embraced the project with open arms to give the public areas in the city greater architectural allure and make them more attractive. Top architects with international reputations were attracted to design the new bridges, quays and parks. The majority of the politicians, civil servants and external parties who were interviewed in the context of our study described the Leie Improvement Project as the most radical public works in the city since many decades.

(3) Buda-island = Arts island. The city of Kortrijk aims to develop Buda-island, located between the arms of the Old and the New Leie, into a sort of artists' retreat (see fig. 1). Although until now it has been difficult to overlook the health care industry's expansion on the island (e.g. rest home, service flats, crèche, etc.), an attempt is being made to use Buda-island to place the city of Kortrijk on the (international) map in terms of culture creation and artistic development. Cultural organisations are being given infrastructure, specialised post-training courses are developed, design projects and innovative economy are getting support, etc. It is essential that all this goes hand in hand with a physical-spatial element. In the spatial development project the Buda-island is incorporated in the morphological carriers of the city (i.e. river Leie and North-South axis) and much emphasis is placed on the creation of public areas and green areas.

Figure 1: Buda Island and the Leie in the centre of Kortijk

\section{Analysis}

\subsection{Mayor De Clerck, former Minister and national party chairman}

During our interviews it became clear that the shift in mayor in 2001 had a huge impact on the city of Kortrijk, the urban policy and the decision-making processes. In general, a more urban mentality, a focus on innovation, creation and design, and mayoral entrepreneurialism were brought in at the cost of social concerns and a traditional government approach. Between 2001 and 2008 (also the end of our research period) Stefaan De Clerck was mayor of Kortrijk. Before that period he held the position of federal Minister of Justice (1995-1998) and that of national chairman of the Christian democratic party (1999-2003). So he combined during a few years two strenuous posts, created a large network at several policy levels, and succeeded in translating his political celebrity in many votes at (local) elections. Mayor De Clerck's personal interests are located in the fields of arts, design, culture and architecture, so it seems self-evident that he was also attracted to UDPs that had the potential to compete with flagship projects in an intercity competition on creativity and innovative economy. While his predecessors did not seem interested in urban transformations and let themselves be guided along in smaller projects, mayor De Clerck strived for innovation and a real 
physical urban transformation of his city. For other local politicians and civil servants the mayor has the reputation of a 'presidential' leader. During the interviews they told us that this leadership style is largely an effect of his ministerial experience. De Clerck was also characterized as energetic but chaotic: "he seems an unguided missile [...] doing a lot of things without formal support and strategic plans". The latter was not always perceived as negative because the interviewees became more and more witness of urban transformations. As we did not opt for a reputation method, we will now jump to the reconstructions of the three decision-making processes (for a lengthy and broad narrative of each case, see Block, 2009). As expected, we may conclude that private actors, semipublic actors and/or supra-local public actors significantly influence UDPs that are carried out in the city centre of Kortrijk. In this analysis we will focus on the dominant role and the strategic behaviour of mayor De Clerck.

\section{2. 'K in Kortrijk': radical policy change and the autonomous municipal company as vehicle}

Our first case analyses a transformational project for Kortijk's shopping area. Which problems did we find in the problem stream? This city had lived for far too long on former commercial success stories (e.g. the first car free pedestrian streets of Flanders in the sixties) and had not sufficiently invested in this important part of the city, while nearby cities had increasingly entered into competition to attract shoppers. As a result, chain stores had left the city centre and other urban deprivation problems had occurred (e.g. a primary school became vacant). Small interventions in the commercial area had not been able to turn the tide (i.e. failure of alternate policy). The 2000 local elections (political stream) brought a new local political leader to power: Stefaan De Clerck. However, neither in the coalition agreement, nor in other policy documents of that period, did we notice that a transformation of the shopping area was expected or was a priority.

In 2001 the new mayor De Clerck became president of the SOK, an urban autonomous municipal company established by means of Flemish initiatives (political stream). Immediately the SOK bought the vacant primary school and noticed that - due to a reorganisation - also the secondary school wanted to withdraw from the heart of the city. These problems leaded to a policy window. In 2003 and after a preparatory study, the mayor asked the SOK to launch a call addressed to private investment companies. Three candidates submitted a proposal that was in line with the call, namely limited and acupunctural interventions. But within the soup of ideas (policy streams), the fourth candidate, the Dutch private investment company Foruminvest suggested a drastic UDP, a transformation of the whole shopping area, and a change of (dis)course (see above: part 3). They immediately got support from the mayor, who - as chairman and composer of the urban design competition jury - grasped the policy window and gave a green light to Foruminvest. Our research results show a strong influence from the investment company within the decision-making process concerning the shopping centre ' $\mathrm{K}$ in Kortrijk'. Representatives of Foruminvest were heavily involved not only in the idea of the urban project but also in working out the details and the execution thereof.

De Clerck defended the new transformative strategy within his informal political networks, decided to sell the grounds of both schools to enlarge the urban project site, and also insisted to cooperate with top architects. The latter fits with his ambition and personal interest to increase the architectural quality of the city. In 2004 the first formal agreement between all involved partners was signed. Under supervision of the mayor, the SOK held the pen and defined the preconditions. In 2005, all actors approved a more elaborated and refined agreement. This agreement also mentioned the establishing of a Business Improvement District around ' $\mathrm{K}$ in Kortrijk'. De Clerck picked up this idea from foreign cases (e.g. US and Germany). 
Due to the 2005 formal agreement, the idea and plans for the shopping complex got a more public character. The engagements and agreements of all involved partners not only influenced (even pushed away) plans of other local politicians and city departments (e.g. mobility and housing), but opened a strained debate on the scale of the project. Local politicians and civil servants evaluated a large shopping complex in the heart of the city as exaggerated. During the interviews these actors made clear that this transformative UDP would have been rejected if they and other stakeholders (e.g. neighbourhood organisations and the public transport company) had been involved from the beginning. However, it was exactly because the mayor did not use the municipal executive (College of Mayor and Aldermen) nor the city council, but rather the SOK as the vehicle to carry out the delicate negotiations with Foruminvest, that this UDP made progress in a rather smooth and fast way.

After the 2006 local elections De Clerck stayed as mayor, although his Christian Democratic Party lost the absolute majority. De Clerck formed a coalition with the Liberal Democrats, not only because they had lower demands and claims than the Socialist Party, but also because of the contested 'neoliberal' shopping complex. Representatives of the Liberal Democrat Party supported his 'creative city' discourse and could give a helping hand to the implementation of this UDP on several occasions (e.g. in 2007, concerning the building permit). In the coalition agreement of both parties, the overall idea, the creation of a Business Improvement District, a design platform and a Building Fund with relation to ' $\mathrm{K}$ in Kortrijk' were mentioned. The latter are new ways to control and renovate the area around the shopping complex. The private investment company, but also the SOK (including De Clerck), seemed in favour of a gentrification process. The construction works started in 2007 and the doors of the shopping complex opened in 2010.

\subsection{Leie Improvement Project: political localism and the intermunicipal cooperation as vehicle}

As mentioned above (cf. part 3), it was around 1992 that the city of Kortrijk finally saw the added value of an important European waterway project to connect and deepen certain rivers and canals between Paris and Antwerp. But the implementation of several successive plans, protocols and agreements was far from successful (Block et al, 2012). The reasons for the delay were multi-faceted: bureaucratic discussions, political games and strategies, discovery of an old belt, national elections, etc. The number of actors involved in this case is relatively high, not in the least because of the divided character of the Flemish Government who is founder and prime contractor in the case of Leie Improvement Project. Ministers, cabinet members and representatives of AWZ/W\&Z (Waterways and Marine Affairs Administration/Waterways and Sea Channels nv) provided financial means and a wide variety of master plans. Also the role of a few employees of the intermunicipal cooperation Leiedal (IMC Leiedal) is quite crucial here. The vision, the innovative suggestions and the professional knowledge of this intermediary organisation provided a strong sense of direction to this project. More than the SOK (cf. case ' $\mathrm{K}$ in Kortrijk'), the employees of IMC Leiedal made their own contribution.

The relevant point in this case is the way mayor De Clerck dealt with supra local governments and IMC Leiedal. At the end of 2000 Stefaan De Clerck became mayor and embraced the unique opportunity ('policy window') immediately to transform the architectural and urban design of Kortrijk. To make sure that the supra-local streams of financial resources ran to his city, he decided to appoint an alderman from the Socialist Party, even though his Christian Democratic Party had obtained an absolute majority. But with this appointment within the political stream, he created a direct line with the relevant Minister in this regard, Steve Stevaert (Socialist Party). As a result, we 
can find in the local coalition agreement of 2000 a quite new discourse and a real plea for a highquality completion of the Leie Improvement Project. Although the negotiations between all actors involved were attended with give-and-take arrangements, the atmosphere between mayor De Clerck and Minister Stevaert was good and useful. The political choice for a Socialist Alderman brought grist to the mill of Kortrijk. As a famous supra-local politician, mayor De Clerck could also count on support of some other politicians. He linked this project also to new plans for Buda Islands (see further) and puts his stamp with design bridges, parks and boulevards. In new plans and protocols, we noticed that the impact of the mayor (officially 'the city council') increased. In March 2003 Minister Stevaert became national chairman of the Socialist party. Gilbert Bossuyt, Socialist mayor of the neighboring municipality Menen, succeeded Stevaert as relevant Minister. He had 'other priorities' with the limited budget (policy and problem stream) and the Leie Improvement Project had to deal with a delay. Due to the 2004 national elections (political stream), a Christian Democratic Minister became responsible and mayor De Clerck brokered immediately the full funding of the Leie Improvement Project. The new Minister said to believe in the vision and UDPs of Kortrijk, and promised full support in (again) new pacts and protocols.

Besides his supra-local (political) network, mayor De Clerck steered this project by his professional and personal relationships within IMC Leiedal. Since 2000, this intermunicipal cooperation was appointed to follow up this UDP for the city of Kortrijk. In reality, they did their job in extensive consultation with the mayor. In formal and informal meetings the mayor always took the lead. As a consequence, representatives and members of the local government and civil servants of the city only played a minor role in the decision-making process. Most of the key figures we interviewed during our research stated honestly that they did not know who decided what during this transformative project. The only exception is Kortrijk's head engineer who gave technical advice to the mayor.

\subsection{Buda Island: coupling (against the) streams}

Before 2000, the cultural policy in Kortrijk was focused on community development and 'low culture'. Interested in 'high culture', modern art, design and architecture, Stefaan De Clerck, as a new mayor, opted for another policy line. Puzzling with an old brewery on the island that earlier had been turned into exercise rooms (for theatre, art and music), an empty and vacant cinema, the literature of Richard Florida and Charles Laundry, the Leie Improvement Project (see above), urban plans of architect Secchi, wishes of the professional art organisations etc., mayor De Clerck interwove all those elements from the problem and policy streams, introduced and promoted the idea of 'Buda island = Art Island', and launched a new discourse and slogan for his city: 'Kortrijk, city of innovation, creation and design'. All interviewees were unanimous: "the Buda Island project is almost a pure De Clerck project".

To get the idea sharp and to convince other stakeholders, De Clerck selected in 2002 three professors to write 'pro domo' academic reports that confirmed or supported his urban policy/project: no smallscale initiatives on Buda Island but the physical spatial development of an arts island as a centre for contemporary art creations to function as a catalyst to give Kortrijk a strong position in an inter-city competition. Via informal political relations and rare formal meetings, this new idea slowly found its way into the city council. Most local politicians and civil servants considered the whole concept as an elite project and a too expensive engagement. The support was very limited, the irritability high. However, De Clerck had the support of the Director of IMC Leiedal and some other local key figures. 
Although the discussion was still going on, De Clerck grasped another 'policy window' and succeeded in submitting a formal application for a UDP, funded by the Flemish Urban Policy (political stream). Particularly important here was a crucial intervention by the former Alderman for town planning and urban development. By pursuing spatial interventions on the degenerating urban island, he was able to get the support of the rank and file of the Christian Democrat Party. Due to the approval of a $€$ 3.000.000 fund of the Flemish government, this UDP reached in 2003 a point of no return (for a discussion on turning points within these UDP processes, see Block et al, 2012). The institutional arrangement that mayor De Clerck installed to control the implementation was not a not-for-profit organization, and as such, it differed from the suggestion in a specific juridical report. De Clerck became chairman of a new autonomous municipal company, 'Buda AGB'.

\section{Conclusions and reflections}

\subsection{Mayoral entrepreneurialism driving force for urban transformations}

Since 2001 in Kortrijk, the centre of gravity of the decision-making concerning transformative urban development projects is not the traditional, hierarchical local government as a whole, but certainly mayor De Clerck. This policy entrepreneur introduces new ambitions, ideas and discourses, continuously connects streams of problems, policies and politics, and uses or creates policy windows (Kingdon, 1984). He also uses and creates institutional positions and several arrangements (Garud et al., 2007) located outside the formal sphere of influence of the traditional urban institutions as strategic springboards. De Clerck interweaves his own power resources and channels with those of others, when and where deemed necessary, and forms in this way power coalitions in which he himself often assumes the role of captain. In this way he enables his preferences (i.e. a combination of interests and ideas) to prevail in the decision-making and policy.

The hybrid character of policy networks concerning innovative and transformative UDPs lends itself readily to such strategic selection behaviour. Certainly in a city like Kortrijk governed by a mayor who is characterised by policy actors as "a creative scale-jumper who coaches very little" and "energetic, innovative and rather impatient", who has experience as a Minister and national party chairman, who (as a result) has an extensive supra-local network, and who directs a relatively discordant municipal executive. Of course, not every city has an entrepreneurial mayor. Anyway, the degree of transferability of our conclusions must be demonstrated from the success of reasoning by analogy that other researchers can make with regard to other urban transformative processes. Besides, as shown in our analysis, the precise timing and form of all connections and the configuration of the governance network are largely determined by the evolving morphology and type of the urban project to which the strategic actions belong.

\subsection{Urban sustainability through entrepreneurial political leadership}

Our aim with this article was to provide a contribution to a better and more precise understanding of the complexity of decision-making in UDPs and the important role of urban entrepreneurial political leadership. In the introduction, we argued that policies and projects that aim for sustainable urban transformations can learn from the experiences described. In this final section, we reflect on possible lessons for sustainability policies and projects in cities.

Policy entrepreneurs, policy windows and the capacity of making connections. The three UDPs we discussed did not appear out of nothing but had a history of several years or decades during which 
ideas were launched and abandoned, preparatory studies were ordered, policies were discussed at urban or regional level. In each case, policy windows can be identified that gave the opportunity to connect problems and policy solutions and propel the case forward. The work that has to be put into connecting these streams is usually done by policy entrepreneurs (Kingdon, 1984) or institutional entrepreneurs (Lowndes, 2005; Garud et al., 2007), people that recognize a possibility for change, see the opportunity to combine agendas, are in a position to do so and are able to convince others to go along. In our cases, the mayor is a central figure in making these connections, but we also notice the role of private actors (i.c. investment companies), important civil servants (such as the head engineer), representatives of an intermunicipal cooperation and of autonomous municipal companies. There is no reason why policies and projects that aim at sustainability should follow a different pattern. Realising sustainable urban transformations will to a large degree depend on combining different policy streams, strategically using opportunities and not in the least on influential and/or powerful people that see the opportunities and are able to make the connections. There is no recipe for such an enterprise, but several elements seem important: discourse development, combining power resources, strategically using networks and 'democratic' institutional arrangements (but not the traditional ones). We elaborate on this in the next paragraphs.

Sustainable urban transformations and discourses of urban leaders. In our previous point, we noted the importance of policy windows and policy entrepreneurs. What is remarkable in the three studied cases, is that these policy windows are accompanied by a change in discourse and a mayor who acts as an active promoter for the new storylines. In each case, relatively small-scale interventions in the city are replaced by far more ambitious flagship projects that fit in an overarching vision on the development of the city: the city as a dynamic, creative, innovative pole in the Flemish region and in the trans-border Eurometropol Lille-Kortrijk-Tournai. One of the important effects of a change in discourse is that it also transforms interests: it redefines the policy problem and in that way leads actors to redefine their interests so that they can align themselves to the new storyline (Hajer, 1994). Our cases show how different kind of actors (investment companies, autonomous municipal companies, intermunicipal cooperation, cultural organisations) are inspired by the new ambitions and form a coalition to defend them. Searching how discourse development can be used, is essential for actors that want to promote sustainable urban transformations. While currently a lot of city policies are still dominated by an inter-city competition and neoliberal storylines, the sustainability storyline has to be turned into an attractive alternative that aligns the interests of important actors. At the moment, urban sustainability is often only translated in small, local ('niche') projects. These may be necessary to experiment and demonstrate practical solutions, but sustainable urban transformations require sustainable UDPs and city-wide programs. Following Coenen et al. (2012), we believe that UDPs focusing on a crucial socio-technical system (e.g. on energy, mobility, housing, food) are able to operate as a catalyst for decisive sustainable transformations. At the moment and certainly in Flemish core cities, this scaling-up needs urban entrepreneurial leaders that create broad discourse coalitions where sustainability functions as a connecting storyline.

Realising results through smart use of power. In order to realise the UDPs in Kortrijk, different forms and channels of power are mobilised and combined by the policy entrepreneurs we identified. What is striking is that most power is mobilised outside the formal urban institutions (city council and college of mayor and aldermen), in particular by the mayor himself. This testifies to the fact that the loci of decision-making are changing from typical government to governance settings and that policymakers are using these new governance spaces and combining the power generated through different formal and informal institutional arrangements to further their preferences. This picture of the use of power differs enormously from the advice that is formulated by some proponents of sustainability transitions to create 'power-free' transition arenas to stimulate transitions. The idea that such arenas should be "relatively safe and free, protected environment[s] without any power 
hierarchy" (Rotmans et al., 2010: 218) will in fact make them powerless. We learned from our cases that government matters, but certainly not in the traditional sense. So we may not confuse the erosion of the forms of government with the erosion of the power of the government (Jessop, 1997; MacLeod et al, 1999). Our results suggest that it is only through the use of power in different settings and through smart combinations of the available power resources that results are achieved. Proponents of sustainable urban transformations will thus have to learn how different forms of power in different settings can be employed and combined to gain influence.

Decision-making networks and the search for democracy. Our previous point - use of power through channels often outside the formal urban institutions - also implies that in the three case studies, decision-making hardly follows the 'normal' democratic routines in city councils, college of mayor and aldermen, and advisory councils. In fact, these traditional democratic bodies are mainly used for informing members of the council or stakeholders and formalising decisions that are taken elsewhere. Decision-making is prepared and often concluded in networks outside these democratic bodies, with a huge impact of the horizontal and vertical networks of the mayor. On the one hand, this fits in with a regularly made observation that established arrangements seem to lack the capacity to formulate solutions for pressing problems and that consequently new governance arrangements are sought after that may be more suited (Hajer et al., 2003). This may thus open new ways for influence for actors promoting sustainable urban transformation. On the other hand, in our cases these new arrangements consist of closed networks where only directly involved stakeholders participate. This may be at odds with the democratic aspirations of the sustainability discourse, where involvement of civil society actors, wide democratic consultation and deliberative forms of democracy are often put forward. This requires further research in which we can base ourselves on primarily European literature that examines the area of tension between 'governance networks' and democracy (cf. Sorensen et al., 2003).

It is obvious that sustainable urban transformations present huge challenges for cities. In particular since urban policies are still mainly focused on inter-city competition (within a neoliberal framework). Still, some change in discourse is visible, but the challenge will be to translate this into real decisions, policies, projects and programmes for sustainability. Although our explained results are related to decision-making of UDPs, we believe that these are transferable to sustainable (urban) transformations. Therefore we use them in two new research project: one on structure and agency dynamics in transition governance processes and experiments, and another on unravelling and reconstructing complex decision-making processes of sustainable urban projects ('Cities in Transition'). We expect a crucial role for the strategic behavior of policy entrepreneurs (politicians as well as civil servants and academics) who couple streams trying to influence the agendas and to promote their ideas for sustainable futures.

\section{Acknowledgements}

This article is based on broader research of Thomas Block on decision-making processes and power configurations in UDPs. This research was supported by the Research Foundation Flanders (FWO). The research of Erik Paredis is supported by the Policy Research Centres Program of the Flemish Government. An earlier version of this article was presented at the international EURA-Conference 'The City without Limits' (Copenhagen, 23-25 June 2011).

\section{References}

AVELINO, F. (2011), Power in Transition: Empowering Discourses on Sustainability Transitions. PhD-Thesis. Rotterdam: Erasmus University Rotterdam 
BAUMGARTNER, F.R., JONES, B.D. (1993), Agendas and Instability in American Politics. Chicago University Press. BERG, R., RAO, N. (2005), Transforming Local Political Leadership. Houndmills: Palgrave.

BLOCK, T. (2009), Van ID naar 3D: besluitvormingsprocessen en beslissingsmacht bij stadsontwikkelingsprojecten ('From ID to 3D: decision-making processes and power configurations within UDPs'). PhD thesis, Ghent University, 380p.

BLOCK, T., STEYVERS, S., OOSTERLYNCK, S., REYNAERT, H., DE RYNCK, F. (2012), When strategic plans fail to lead. A complexity-acknowledging perspective on decision-making in urban projects. The case of Kortrijk. European Planning Studies, 20, 6, pp.981-997.

BORRAZ, O., JOHN, P. (2004), The Transformation of Urban Political Leadership in Western Europe. International Journal of Urban and Regional Research, 28, 1, pp.107-120.

BULKELEY, H., CASTAN BROTO, H., HODSON, M., MARVIN, S. (2011), Cities and low carbon transitions, Routledge, Oxon.

COHEN, M.D., MARCH, J.G., OLSEN, J.P. (1972), A garbage can model of organizational choice. Administrative Science Quarterly, 17, pp.1-25.

DAHL, R. (1961), Who Governs? Democracy and power in an American city. New Haven: Yale University Press.

DIMAGGIO, P. (1988), Interest and agency in institutional theory. ZUCKER, L. (ed.), Institutional patterns and culture, Cambridge: Ballinger Publ. Company, pp.3-22.

GEELS, F.W., SCHOT, J. (2007), Typology of socio-technical transition pathways. Research Policy, 36, 3, pp.99417.

GARUD, R., HARDY, C., MAGUIRE, S. (2007), Institutional entrepreneurship as embedded agency. Organization Studies, Special issue on 'institutional entrepreneurship, 28, 7, pp.957-969.

GIDDENS, A. (1984), The constitution of Society. Berkeley: California University Press.

GREASLEY, S., STOKER, G. (2008), Mayors and urban governance. Developing a facilitative leadership style. Public Administration Review, 68, 4, p.722-730.

GRIN, J. (2010), Understanding transitions from a governance perspective. GRIN, J., ROTMANS, J., SCHOT, J., Transitions to Sustainable Development. New Directions in the Study of Long Term Transformative Change, Oxon: Routledge, p.221-319.

GRIN, J., ROTMANS, J., SCHOT, J. (2010), Transitions to Sustainable Development. New Directions in the Study of Long Term Transformative Change, Oxon: Routledge.

HAJER, M.(1994), The Politics of Environmental Discourse. Ecological Modernisation and the Policy Process, Oxford: Oxford University Press.

HAJER, M., WAGENAAR, H. (2003), Introduction. HAJER, M., WAGENAAR, H. (eds.), Deliberative Policy Analysis: Understanding Governance in the Network Society, Cambridge: Cambridge University Press, p.1-30.

HEALEY, P. (2007), Urban Complexity and Spatial Strategies. London: Routledge.

HODSON, M., MARVIN, S. (2010), Can cities shape socio-technical transitions and how would we know if they were? ResearchPolicy, 39, 4, pp.477-485.

JESSOP, B. (1997), A neo-Gramscian approach to the regulation of urban regimes: accumulation strategies, hegemonic projects, and governance. LAURIA, M., (ed.), Reconstructing urban regime theory. London: Sage, pp.51-73.

JOHN, P. (2001), Local Governance in Western Europe. London: Sage.

KINGDON, J.W. (1984 [2011]), Agendas, alternatives and public policies. Boston: Little, Brown and Company.

KLIJN, E.H. (1996), Analyzing and managing policy processes in complex networks: A theoretical examination of the concept Policy Network and its problems. Administration \& Society, 28, 1, pp.90-119.

KLIJN, E.H. (2008), Governance and governance networks in Europe. Public Management Review, 10, 4, pp.505525.

KOPPENJAN, J., KLIJN, E. (2004), Managing uncertainty in networks: a network approach to problem solving and decision making, London: Routledge.

LOORBACH, D. (2007), Transition Management, new mode of governance for sustainable development, Utrecht: International Books.

LOWNDES, V. (2005), The institutional approach. MARSH, D., STOKER, G., Theory and Methods in Political Science, Hampshire: Palgrave MacMillan, p.60-79.

LOWNDES, V., LEACH, S. (2004), Understanding local political leadership: Constitutions, contexts and capabilities. Local Government Studies, 30, 4, p.557-575.

MACLEOD, G., GOODWIN, M. (1999), Space, scale and state strategy: rethinking urban and regional governance. Progress in Human Geography, 23, 4, pp.503-527. 
MAGUIRE, S., HARDY, C., LAWRENCE, T. (2004), Institutional entrepreneurship in emerging fields. Academy of Management Journal, 47, pp.657-679.

MARSH, D. (ed.) (1998), Comparing Policy Networks. Buckingham: Open University Press.

MEADOWCROFT, J. (2011), Engaging with the politics of transitions. Journal of Environmental Innovation and Societal Transitions, vol. 1, 1, p. 70-75.

MILES M.B., HUBERMAN A.M. (1984), Qualitative Data Analysis: A Sourcebook of New Methods. Newbury Park, $C A$ : Sage.

MINTROM, M. (1997), Policy entrepreneurs and the diffusion of innovation. American Journal of Political Science, 41, 3, pp.738-770.

PARKER, S. (2011), Cities, Politics and Power. New York: Routledge.

PIERRE, J. (1998), Partnerships in urban governance: European and American experience. London: Macmillan.

ROTMANS, J., LOORBACH, D. (2010), Towards a better understanding of transitions and their governance: a systemic and reflexive approach. GRIN, J., ROTMANS, J., SCHOT, J. (eds.), Transition to Sustainable Development. New Directions in the Study of Long Term Transformative Change, New York: Routledge, pp.105-220.

SALET, W., GUALINI, E. (Eds) (2006), Framing Strategic Urban Projects: Learning from Current Experiences in European urban Regions. London: Routledge.

SCRASE, J.I., SMITH, A. (2009), The (non-)politics of managing low carbon socio-technical transitions Environmental Politics 18, 5, pp.707-726

SEO, M., CREED, D. (2002), Institutional contradictions, praxis and institutional change: a dialectic perspective. Academy of Management Review, 27, pp.222-248.

SORENSEN, E., TORFING, J. (2003), Network politics, political capital and democracy. International Journal of Public Administration. 26, 6, pp.609-634.

STEYVERS, K., BERGSTRÖM, T., BÄCK, H., BOOGERS, M., RUANO DE LA FUENTE, J., SCHAAP, L. (2008), From Princeps to President? Comparing Local Political Leadership Transformation. Local Government Studies, 34, 2, pp.131-146.

STRN (2010), A mission statement and research agenda for the Sustainability Transitions Research Network, www.transitionsnetwork.org, 27p.

SWYNGEDOUW, E., MOULAERT, F., RODRIGUEZ, A. (2002), Neoliberal Urbanization in Europe: Large-Scale Urban Development Projects and the New Urban Policy. In: Antipode, 34, 3, pp.542-577.

TEISMAN, G. (2000), "Models for Research into Decision-Making Processes: On Phases, Streams and DecisionMaking Rounds". Public Administration, 78, 4, pp.937-956.

TEISMAN, G., KLIJN, E-H., (2008), Complexity theory and public management. Public Management Review, 10, 3, pp.287-297.

VOß, J.P., SMITH, A., GRIN, J. (2009), Designing long-term policy: rethinking transition management. Policy Sciences, 42, 4, pp.275-302

YIN, R.K. (1984), Case study research. Design and methods. London: Sage.

ZAHARIADIS, N. (2007), The multiple streams framework: structure, limitations, prospects. In: SABATIER, P.A. (ed.), Theories of the Policy Process. Boulder, CO: Westview Press, pp.65-92. 